\title{
Impact of PKV Mini Dal Mill on its Owners: A Case Study
}

\author{
Rupali D. Pimpalkar*, R. T. Katole, Preeti Todasam and Prajakta D. Chavhan \\ Department of Extension Education, Post Graduate Institute, Dr. Panjabrao Deshmukh Krishi \\ Vidyapeeth, Akola, Maharashtra, India \\ *Corresponding author
}

\section{A B S T R A C T}

Keywords

PKV mini Dal Mill, Case study, Annual income, Social Participation, Material possession, Employment generation

\section{Article Info}

\section{Accepted:}

18 December 2020

Available Online:

10 January 2021
The study entitled "Impact of PKV Mini Dal Mill on its owners: a case study" was carried out in the Akola and Amravati districts of the Vidarbha region. For this study, a list of owners of PKV Mini Dal Mill who started their plant from 2015-2016 was collected from the Department of Post Harvest Engineering and Technology, College of Agricultural Engineering and Technology, Dr.P.D.K.V. Akola. A sample of ten owners of PKV Mini Dal Mill was taken from the districts of Akola and Amravati. The impact of PKV Mini Dal Mill on its owners has been studied in terms of changes in annual income, changes in social participation, changes in material possession and changes in employment generation. It was found that there was a change in annual income, social participation, material possession and generation of employment. The total change was found to be $48.29 \%$. While reviewing the results of this study, it was found that $80.00 \%$ of respondents had a high level of change in their annual income. It was also found that $60.00 \%$ of respondents had a medium level of change in their social participation. It was also revealed that 90.00 per cent respondents have high level of change in their material possession whereas 70.00 per cent respondents have high level of change in their employment generation.

\section{Introduction}

India is the world's largest producer of pulses. In the country, pulses are mostly consumed in the form of dal, dehusked and split kernel.

Almost $75 \%$ of the total production of legumes is converted into dal. The milling of edible pulses for the production of dal is an old process. Milling procedures vary widely from location to location. Thus, the recovery of dal varies from 60 to $75 \%$ depending on the type of pulses, techniques and mills used by the millers. Pulses are a source of supplementary protein in daily diets based on cereals and starchy foods for the predominantly vegetarian population and for those who cannot afford expensive animals. Pulse are therefore, often regarded as poor men's meat. They also provide energy, essential minerals, vitamins and a number of compounds that are considered beneficial to good health. India, the world's largest producer (18.5 million tonnes) and pulse processor, also imports an average of around 3.5 million tonnes annually to meet its ever- 
increasing consumption needs of around 22.0 million tonnes. The PKV Mini Dal Mill is commercialised and successfully used by people. The unit is mainly intended for the preparation of pulse splits (dal) of pigeon, black gram, green gram, soya, etc.

As the production of pulses in Vidarbha region of Maharashtra state is increasing day by day, the Akola and Amravati districts of Vidarbha region are important according to pulse processing point of view. Keeping this in point of view of small farmers, PKV Mini Dal Mill, which is a compact mini dal mill with all essential operations, has been developed at Dr.PDKV, Akola.This dal mill is compact in size its construction is simple and very easy to handle. This consists of vertical grinding stones that are used for the splitting of pulses. The shelled dal is passed through grinding stone with the help of hopper. The stones are provided with various sizes of lines for different dals being processed. The removal of the outer layer and splitting the grain into two equal parts is called as pulse milling.

\section{Materials and Methods}

The present investigation was conducted to study the impact of PKV Mini Dal Mill on its owners: A Case Study in Akola and Amravati districts. Therefore, a case study method of social research design was used for present study aims at assessing the case study of PKV Mini Dal Mill owners. Case study - The case study is a form of qualitative analysis involving the very careful and complete observation of a person, a situation or an institution

For this study, a list of owners of PKV Mini Dal Mill who started their plant from 20152016 was collected from the Department of Post Harvest Engineering and Technology, College of Agricultural Engineering and
Technology, Dr.P.D.K.V. Akola. A sample of ten owners of the PKV Mini Dal Mill was taken from the districts of Akola and Amravati.

\section{Results and Discussion}

Table 1 shows that only (20 per cent) of the owners of PKV Mini Dal Mill had an annual income of up to Rs. 60,000/-before the adoption of PKV Mini Dal Mill, followed by 70 per cent of the owners of PKV Mini Dal Mill had an annual income of more than Rs. $1,20,000 /$-rope and only 10 per cent had an annual income of between Rs. 60,001/-and Rs. 1,20,000/-before the adoption of PKV Mini Dal Mill.

In the case of PKV Mini Dal Mill, (00 per cent) of the owners of PKV Mini Dal Mill had an annual income of up to Rs. 60,000/-, followed by an annual income of 20.00 per cent between Rs. 60.001/-and Rs. 1,20,000/and a majority of 80.00 per cent of the owners of PKV Mini Dal Mill had an income of more than $1,20,000 /-$.

Table 2 shows that 50.00 per cent of PKV Mini Dal Mill owners had a medium level of social participation followed by 40.00 per cent had a low level of social participation and 10.00 per cent had a high level of social participation prior to the adoption of PKV Mini Dal Mill.

In the case of PKV Mini Dal Mill, the majority (60 per cent) of PKV Mini Dal Mill owners had a medium level of social participation, followed by a high level of social participation of 30 per cent and a low level of social participation of 10 per cent.

It is therefore concluded that the majority of owners of PKV Mini Dal Mill had a medium level of social participation. 
Table 3 reveals that 60.00 percent of PKV Mini Dal Mill owners had a medium level of social material possession, followed by 40.00 percent having a high level of social material possession, and 00.00 percent had a low level of material possession before the PKV Mini Dal Mill business was adopted.

Table.1 Distribution of the PKV Mini Dal Mill owners according to their annual income

\begin{tabular}{|l|l|c|c|c|c|}
\hline \multirow{2}{*}{$\begin{array}{c}\text { SI. } \\
\text { No. }\end{array}$} & Annual Income & \multicolumn{2}{|c|}{$\begin{array}{c}\text { Before adoption of PKV } \\
\text { Mini Dal Mill }\end{array}$} & \multicolumn{2}{c|}{$\begin{array}{c}\text { After adoption of PKV } \\
\text { Mini Dal Mill }\end{array}$} \\
\cline { 3 - 6 } & & Frequency & Per cent & Frequency & Per cent \\
\hline 1. & Up to 60,000/- & 02 & 20.00 & 00 & 00.00 \\
\hline 2. & 60,001/- to 1,20,000/- & 07 & 70.00 & 02 & 20.00 \\
\hline 3. & Above 1,20,000/- & 01 & 10.00 & 08 & 80.00 \\
\hline & Total & $\mathbf{1 0}$ & $\mathbf{1 0 0}$ & $\mathbf{1 0}$ & $\mathbf{1 0 0}$ \\
\hline
\end{tabular}

Table.2 Distribution of the PKV Mini Dal Mill owners according to their social participation

\begin{tabular}{|l|c|c|c|c|c|}
\hline \multirow{2}{*}{$\begin{array}{c}\text { Sl. } \\
\text { No. }\end{array}$} & Social Participation & \multicolumn{2}{|c|}{$\begin{array}{c}\text { Before adoption of PKV } \\
\text { Mini Dal Mill }\end{array}$} & \multicolumn{2}{c|}{$\begin{array}{c}\text { After adoption of PKV } \\
\text { Mini Dal Mill }\end{array}$} \\
\cline { 3 - 6 } & & Frequency & Per cent & Frequency & Per cent \\
\hline 1. & Low & 04 & 40.00 & 01 & 10.00 \\
\hline $\mathbf{2 .}$ & Medium & 05 & 50.00 & 06 & 60.00 \\
\hline $\mathbf{3 .}$ & High & 01 & 10.00 & 03 & 30.00 \\
\hline & Total & $\mathbf{1 0}$ & $\mathbf{1 0 0}$ & $\mathbf{1 0}$ & $\mathbf{1 0 0}$ \\
\hline
\end{tabular}

Table.3 Distribution of the PKV Mini Dal Mill owners according to their material possession

\begin{tabular}{|c|c|c|c|c|c|}
\hline \multirow[t]{2}{*}{$\begin{array}{l}\text { Sl. } \\
\text { No. }\end{array}$} & \multirow[t]{2}{*}{ Material possession } & \multicolumn{2}{|c|}{$\begin{array}{c}\text { Before adoption of PKV } \\
\text { Mini Dal Mill }\end{array}$} & \multicolumn{2}{|c|}{$\begin{array}{l}\text { After adoption of PKV } \\
\text { Mini Dal Mill }\end{array}$} \\
\hline & & Frequency & Per cent & Frequency & Per cent \\
\hline 4. & Low & 00 & 00.00 & 00 & 00.00 \\
\hline 5. & Medium & 06 & 60.00 & 01 & 10.00 \\
\hline \multirow[t]{2}{*}{6.} & High & 04 & 40.00 & 09 & 90.00 \\
\hline & Total & 10 & 100 & 10 & 100 \\
\hline
\end{tabular}

Table.4 Distribution of the PKV Mini Dal Mill owners according to employment generation

\begin{tabular}{|c|c|c|c|c|c|}
\hline \multirow[t]{2}{*}{$\begin{array}{l}\text { Sl. } \\
\text { No. }\end{array}$} & \multirow[t]{2}{*}{ Employment generation } & \multicolumn{2}{|c|}{$\begin{array}{c}\text { Before adoption of PKV } \\
\text { Mini Dal Mill }\end{array}$} & \multicolumn{2}{|c|}{$\begin{array}{l}\text { After adoption of PKV } \\
\text { Mini Dal Mill }\end{array}$} \\
\hline & & Frequency & Per cent & Frequency & Per cent \\
\hline 1. & Low & 00 & 00.00 & 00 & 00.00 \\
\hline 2. & Medium & 00 & 00.00 & 03 & 30.00 \\
\hline \multirow[t]{2}{*}{3.} & High & 00 & 00.00 & 07 & 70.00 \\
\hline & Total & 00 & 00 & 10 & 100 \\
\hline
\end{tabular}


Table.5 Impact of PKV Mini Dal Mill on its owners

\begin{tabular}{|l|l|c|c|c|}
\hline \multirow{2}{*}{$\begin{array}{l}\text { Sl. } \\
\text { No. }\end{array}$} & \multicolumn{1}{|c|}{ Impact Dimension } & \multicolumn{2}{|c|}{ Mean score } & \multirow{2}{*}{$\begin{array}{c}\text { Per cent } \\
\text { change }\end{array}$} \\
\cline { 3 - 5 } & & $\begin{array}{c}\text { Before adoption } \\
\text { of PKV Mini Dal } \\
\text { Mill }\end{array}$ & $\begin{array}{c}\text { After adoption of } \\
\text { PKV Mini Dal } \\
\text { Mill }\end{array}$ & \\
\hline 1. & Change in annual income & 124975 & 212798 & 35.75 \\
\hline 2. & Change in social participation & 8.52 & 11.89 & 31.29 \\
\hline 3. & Change in material possession & 42.65 & 66.25 & 28.16 \\
\hline 4. & $\begin{array}{l}\text { Change in employment } \\
\text { generation }\end{array}$ & 00.00 & 74.00 & 34.55 \\
\hline & \multicolumn{1}{|c|}{ Mean } & & & \\
\hline
\end{tabular}

Most (90 percent) of PKV Mini Dal Mill owners had a high level of material possession after the adoption of the PKV Mini Dal Mill venture, followed by 10.00 percent with a medium level of material possession and 00.00 percent with a low level of material possession.

Therefore, it is concluded that the majority of owners of PKV Mini Dal Mill had a high level of material possession after PKV Mini Dal Mill was adopted.

It is obvious from Table 4 that the majority (70\%) of PKV Mini Dal Mill owners had a high level of job generation after the adoption of the PKV Mini Dal Mill enterprise, followed by $30,00 \%$ with a medium level of job generation and $00,00 \%$ with a low level of job generation.

It is therefore concluded that the majority of owners of PKV Mini Dal Mill had a high level of job generation after the adoption of the PKV Mini Dal Mill sector.

A cursory look at Table 5 showed that the mean score of owners after starting PKV Mini Dal Mill for change in annual income (212798), change in social participation (11.89), change in material possession (66.25) and change in work generation (74.00) was higher than the mean score for change in annual income before starting PKV Dal Mill (212792), change in social participation (74.00).

It was also found that there was change in annual income, social participation, material possession and employment generation to the tune of $35.75,31.29,28.16$ and 34.55 per cent over that before starting the PKV Mini Dal Mill owners. Because of the starting the PKV Mini Dal Mill enterprise, it resulted change inannual income, social participation, material possession and employment generation.

When impact as whole was considered it is seen from the Table that there was overall impact of 48.29 per cent of starting PKV Mini Dal Mill enterprise on its owners. It could therefore there was definite positive impact of starting PKV Mini Dal Mill enterprise on its owners in terms of change inannual income, social participation, material possession and employment generation to the extent of 48.29 per cent over and above as a whole.

The results of the study revealed that overall impact of PKV Mini Dal Mill unit on its owners was beneficial to them. It is also found that very few respondents had Dal Mill through government subsidy hence it is also necessary to create awareness regarding 
subsidy. Most of the village people are unaware about the PKV Mini Dal Mill unit. Efforts should be taken to create more awareness in this content through training programmes, demonstration, etc.

\section{References}

Deshmukh, J.M., V.D. Hyalij, D.D. Suradkar and B.B. Badgire, 2017. Impact assessment of farm ponds on beneficiaries. Int. J. Curr. Microbio. App. Sci.6(9): 1712-1717.

Dhorey, R. K., Pavan kumar, P., and S. N. Singh. 2019. Profile Characteristics of Farmers in Adoption of Bt.Cotton. Int. J.Curr.Microbiol.App.Sci. 8 (01): 23732378.

Gupta, J.P. and S. Kumar,2001. Status of power tillage use in Bihar - a case study in Nalanda district. Agricultural Mechanization in Asia, Africa and Latin America. 32(1):19-22.

Khajuria R., F.L. Sharma. And B. Podikunju,2003. Communication behaviour of farmers for seeking information about sprinkler irrigation technology. Maharashtra J. of Extn.Educ.22:30

Kumar, S., G. Sharma and V. K. Yadav. (2013). Factors influencing entrepreneurial behaviour of vegetable growers. Indian Res. J. Ext. Edu.; 13 (1): 16-19.

N.V.Shende.2013.Technology adoption and their impact on farmers: A case study.AsianResonance.Vol-II,ISSUEIV,ISSN No. 0976-8602.

\section{How to cite this article:}

Rupali D. Pimpalkar, R. T. Katole, Preeti Todasam and Prajakta D. Chavhan. 2021. Impact of PKV Mini Dal Mill on its Owners: A Case Study. Int.J.Curr.Microbiol.App.Sci. 10(01): 28022806. doi: https://doi.org/10.20546/ijcmas.2021.1001.323 